\title{
RETHINKING THE POSITION OF ETHNIC CHINESE INDONESIANS
}

\author{
Chong Wu Ling
}

\begin{abstract}
This article examines the position of ethnic Chinese Indonesians from the pre-colonial period to the post-Suharto era, and factors that were at play. Chinese Indonesians experienced various discrimination and attacks ever since the Dutch colonisation period and, most severely, during the Suharto's presidency (1966-1998). Under Suharto, the state perceived them as the potential 'fifth column' for China; thus, imposing upon them forced assimilation, restriction from politics, public service, military and entrance to public universities, and to finally coerce them to abandon their ethnic and cultural identity. Furthermore, attacks against the Chinese reached its climax in May 1998 amid the Asian financial crisis when riots against the Chinese broke out in many parts of the country. However, the condition of the Chinese improved significantly after the end of the Suharto regime on 21 May 1998 and following the rise of open-minded Indonesian political leaders as well as the rise of China as an economic power. This article concludes that the position of ethnic Chinese Indonesians was shaped by not only the interests and agendas of the power-holders but also the anti-communist politics associated with the Cold War, the rise of open-minded Indonesian political leaders, IndonesiaChina relations and the globalisation of the economic position of China.
\end{abstract}

\section{Introduction}

The ethnic Chinese have always been a small minority in Indonesia. In 1930 they represented an estimated 2.03 per cent of the total population. ${ }^{1}$ It was estimated that Chinese Indonesians formed about 1.2 per cent of the total Indonesian population in both 2000 and 2010. ${ }^{2}$ Despite their small proportion in the country, it has been widely acknowledged that ethnic Chinese Indonesians have played an important and vital role in the economic development of Indonesia. However, it is also undeniable that nowhere have more ethnic Chinese been discriminated and persecuted during the past centuries than in Indonesia. Various discrimination and attacks against the Chinese had already taken place during Dutch colonisation. The discrimination against the Chinese was most severe during Suharto's presidency (1966-1998) as the state imposed forced assimilation upon them, coercing them to abandon their ethnic and cultural identity, but at the same time still stigmatising them as Chinese and restricting them from politics, public service, military and entrance to public universities. Furthermore, attacks against the Chinese reached its climax in May 1998 amid the Asian financial crisis when riots against the Chinese broke out in many parts of the country especially Medan, Jakarta and Solo. It was even alleged that many Chinese women were brutally tortured, raped and murdered. Suharto's rule ended amid the financial crisis when he resigned on 21 May 1998. Ironically, the post-Suharto era saw the significant improvement in the condition and position of ethnic Chinese Indonesians.

This article examines the position of ethnic Chinese Indonesians from the precolonial period to the post-Suharto era. This article looks at major legislation related to Chinese Indonesians and major literature on this minority group to identify the factors that shaped their position in the aspects of economy, socio-cultural sphere and politics.

\section{Pre-colonial Period and Dutch Colonial Rule}

The Chinese were already residents in Java and coastal communities of the Maluku Islands, Sulawesi, Sumatra and Kalimantan before the arrival of the Dutch. The Chinese settled in 
the Indonesian archipelago for trading purposes. ${ }^{3}$ Many local regents appointed Chinese merchants as intermediary traders between themselves, the indigenous population, and external markets. These local regents preferred the Chinese to the indigenous population to fill this occupational niche in order to prevent the rise of an indigenous merchant class that might challenge their position. ${ }^{4}$ In pre-colonial times, the Chinese in Java and other parts of Southeast Asia could assimilate into the indigenous population, because increasingly numbers of those who travelled to Southeast Asia for trade were themselves Muslim. ${ }^{5}$

Under Dutch colonial rule, which began in the seventeenth century, the Chinese could no longer be completely assimilated into the indigenous society. According to Mona Lohanda, in the days of the Dutch East India Company (VOC) during the seventeenth and eighteenth centuries, the people in the Indonesian archipelago were classified into Christians and non-Christians and on a racial basis, westerners (Europeans) and non-westerners (nonEuropeans). Each non-western ethnic group was ruled by local headmen appointed by the VOC. All Chinese from different speech groups (e.g. Hokkien, Hakka and Hainan) were classified as Chinese. The headman of the Chinese community in each locality was known as 'Kapitan Cina' (Chinese captain). ${ }^{6}$ Like the local regents before them, the VOC used the Chinese as middlemen between the Dutch and the indigenous population. ${ }^{7}$ After the collapse of the VOC in 1800, its territories were taken over by the Dutch colonial government. In 1854, the colonial government divided the population of the Dutch East Indies into three groups. ${ }^{8}$ The first group was European who formed the upper level. The middle level was Foreign Orientals, which included the Chinese, Arabs, Indians and Japanese who were born in the Dutch East Indies or had resided there for 10 years or above. The bottom level was the indigenous population. ${ }^{9}$ According to The Siauw Giap, it was this stratification which made Islam less attractive to the Chinese, because Muslims were considered indigenous people with a status inferior to that of the Chinese. ${ }^{10}$

Under Dutch rule, Chinese business people became indispensable to the colonial economy. The colonial government granted Chinese licenses to engage in "the selling of opium, the operation of gambling establishments, ferries, pawnshops, and abattoirs, and the gathering of birds' nests for export to the gourmets of China". ${ }^{11}$ Such a monopoly concession system was known as revenue or tax farming and the license holder was known as a revenue farmer. ${ }^{12}$ Among all monopoly concessions the opium concession was the most lucrative. ${ }^{13}$ The monopoly concession system produced many wealthy Chinese revenue farmers.

In order to prevent the Chinese and the indigenous people from combining forces to challenge them, the Dutch introduced zoning and pass systems in 1835 and 1863, respectively, that required the Chinese to reside in restricted areas and prevented them from travelling out of these areas unless they had passes..$^{14}$ These systems effectively prevented the Chinese from living among the indigenous population and restricted interaction between the Chinese and other ethnic groups. The Chinese therefore began to occupy an ambivalent position in Indonesian society during Dutch rule. On the one hand, they played a crucial role in the colony's economic development. On the other hand, the Chinese began to be perceived as the "Other" because of this and were increasingly regarded with suspicion and prejudice by the indigenous majority.

In the 1890s, Dutch humanitarians pressured the colonial government to abolish the revenue farming system, since they saw it as detrimental to the welfare of the indigenous population. ${ }^{15}$ This move broke part of the Chinese economic power. The Chinese in Indonesia were also further angered when, in 1899, after the defeat of China in the First Sino-Japanese War (1894-1895), the Dutch government acceded to the Japanese government request to classify the Japanese in the Dutch East Indies as Europeans. ${ }^{16}$ Although the Chinese also demanded equal status with Europeans, the Dutch rejected this demand as the 
colonial government was concerned that the concession would exert a considerable impact on the growing nationalist forces among indigenous Indonesians. ${ }^{17}$

At the same time, political events in China stimulated the nationalist sentiments of the Chinese in the Dutch East Indies. China had been invaded by foreign powers in the nineteenth century, losing in the Opium War (1840-1842) to the British and suffering an immense defeat in the First Sino-Japanese War (1894-1895). After the Boxer Uprising in 1900, Beijing was invaded and plundered by the allied armies, an alliance of the armies of AustriaHungary, France, Germany, Italy, Japan, Russia, the United Kingdom (UK) and the United States (US). ${ }^{18}$ Two prominent Chinese political leaders, K'ang Yu-wei and Sun Yat-sen, sought to rescue China "while living in exile among the overseas Chinese". ${ }^{19} \mathrm{~K}$ 'ang was a reformist while Sun was a revolutionary. The Chinese in the Dutch East Indies, who had suffered great loss of prestige, could identify with the difficulties of China and offered financial support to both $\mathrm{K}^{\prime}$ ang and Sun with the hope to "contribute to the future greatness of their ancient homeland" ${ }^{20}$ In addition, the lifting of the prohibition of Chinese emigration by the Manchu government (Qing Dynasty) in 1894 and the issuance of the Chinese nationality law in 1909 which was based on jus sanguinis and claimed that every legal or extra-legal child of Chinese father or mother would be considered a Chinese citizen, regardless of birthplace further strengthened the nationalist sentiments of the Chinese in the Indonesian archipelago. ${ }^{21}$

These various factors contributed to the Pan-Chinese Movement in the Dutch East Indies, which revolted against the restrictions placed on the Chinese, particularly the zoning and pass systems. 'Pan-Chinese Movement' is a term used by scholars such as Lea E. Williams, Leo Suryadinata and Ming Govaars to refer to the emergence of nationalist sentiments oriented toward China and the revival of Chinese culture among the peranakan Chinese, i.e. local-born and acculturated Chinese, in early twentieth century Dutch East Indies. ${ }^{22}$ The peranakan Chinese tried to preserve their Chinese identity and safeguard their business as well as political interests by forming various Chinese organisations. These included the Tiong Hoa Hwe Koan (THHK), a Chinese organisation which promoted Chinese nationalism based on the teachings of Confucius through the Chinese-medium schools set up by the organisation in the Indies; the Siang Hwee (Chinese Chamber of Commerce) that championed the interests of Chinese business and community; and the Soe Po Sia (Chinese reading club) which disseminated modern political ideas through the distribution of reading materials. ${ }^{23}$ The peranakan Chinese also established newspapers in Bahasa Melajoe Tionghoa (Sino-Malay language) such as Li Po, Chabar Perniagaan/Perniagaan, Pewarta Soerabaia, Djawa Tengah and Sin Po to promote Chinese nationalism and Chinese culture. ${ }^{24}$

In order to curb Chinese nationalism, and placate the Pan-Chinese movement, the colonial government passed a nationality law in 1910 based on jus soli which declared that all persons born in the Indies of parents residing there were Dutch subjects even if not Dutch citizens. ${ }^{25}$ Thus, the Indies-born Chinese were both Chinese citizens and Dutch subjects. ${ }^{26}$ Later in 1917 and 1918, the Dutch abolished the hated zoning and pass systems. ${ }^{27}$

Takashi Shiraishi, however, argues that these systems restricting Chinese movement and residence were abolished because the Dutch saw that anti-Sinicism was already firmly in place among indigenous Indonesians in the early 1910s as a result of the rise of new nationalist politics that emphasised racial distinctions. Hence, it was no longer necessary to require Chinese and indigenous people to reside in different quarters. ${ }^{28} \mathrm{In}$ fact, the abolishment of both systems in the late 1910s did not bring significant improvement in interactions and relations between the Chinese and the indigenous population. Many pribumi (indigenous people) perceived the Chinese as foreigners who were culturally different from the indigenous population. ${ }^{29}$ They also believed that the Chinese were economically strong but exclusive and selfish. ${ }^{30}$ 
It should be noted that the political orientation of the Chinese was never homogeneous. Apart from the pro-China Chinese, there were also pro-Dutch and proIndonesian Chinese during the Dutch colonial period. The pro-Dutch Chinese were represented by Chung Hwa Hui $(\mathrm{CHH})$, a Chinese organisation founded by wealthy Chinese businessmen while the pro-Indonesian Chinese were represented by the Indonesian Chinese Party (PTI - Partai Tionghoa Indonesia), a Chinese political party that supported the Indonesian nationalist movement. Nevertheless, PTI was never a strong party as it was not supported by wealthy Chinese businessmen who were mostly pro-Dutch. The party was also not regarded as an Indonesian party by the Indonesian nationalist movement. ${ }^{31}$

In addition, the Dutch allowed the Chinese to establish Chinese-language newspapers. Most of such newspapers were managed by totok Chinese, i.e. pure-blood Chinese who were born in China and migrated to the Indies. ${ }^{32}$ In fact, it can be said that the Dutch allowed the Chinese to form ethnic-based organisations, establish Chinese-language presses and open Chinese-medium schools because they wanted the Chinese to maintain their "Chinese-ness" in order to keep them as a distinct ethnic group and prevent them from mingling with the indigenous population.

The loyalty of the Chinese to the Indies was also doubted by many pribumi. Before independence, the Chinese were often suspected of allying with the Dutch and China. ${ }^{33}$ Such stereotypes and prejudice manifested in anti-Chinese violence that broke out in several places in Indonesia during the early phase of the Revolution (1945-1946). ${ }^{34}$ Many Chinese traders were attacked because they were deemed as rivals of indigenous small businesses. Some Chinese were caught in the riots because they were suspected of being in league with the Dutch. ${ }^{35}$

\section{The Sukarno Years (1950-1965)}

After independence, some indigenous leaders assumed that the Chinese were oriented to China instead of Indonesia. ${ }^{36}$ Many Chinese in Indonesia, especially those who were recent immigrants, had a strong sense of pride in China. ${ }^{37}$ The victory of the communists in China in 1949 triggered Chinese nationalism among Chinese Indonesians and prompted some Chinese Indonesians to return to China to receive further Chinese-language education and to build their ancestral land. ${ }^{38}$ In the eyes of some indigenous Indonesian leaders, the Chinese minority was oriented toward China. They therefore perceived the Chinese minority as a potential 'fifth column' for China. ${ }^{39}$ They were therefore uncomfortable with the dual citizenship of the Chinese that emerged again out of the relatively liberal the Citizenship Act of 1946 (Law No. 3/1946) and the Round Table Agreement on Citizenship in 1949 between Indonesia and the Netherlands. Under these provisions, those Chinese who had been Dutch subjects and did not reject Indonesian citizenship were considered as citizens of both Indonesia and China. ${ }^{40}$ For many indigenous nationalists, as Chang-Yau Hoon puts it, "dual nationality meant that the political loyalty of the Chinese must be divided between Indonesia and China". ${ }^{41}$ Moreover, during the 1955 Bandung AsianAfrican Conference, China abandoned its traditional claim that all ethnic Chinese were Chinese citizens..$^{42}$ Both President Sukarno and the Chinese prime minister, Zhou Enlai, agreed that ethnic Chinese should choose only one citizenship. ${ }^{43}$ Hence, in 1958, a new and less liberal citizenship act known as Law No. 62/1958 was passed. Under the new act, Chinese in Indonesia would lose their citizenship if they did not submit an official statement abjuring Chinese citizenship. ${ }^{44}$ However, the act was only fully implemented in 1960, thus leaving the citizenship of most Chinese in an ambiguous state between 1958 and 1960.45 In November 1959, as part of the steps towards reducing the economic role of ethnic Chinese, the government issued Presidential Decree No. 10 that banned "alien" (i.e. Chinese) retail trade in rural areas and required all the aliens to transfer their business to Indonesian 
citizens by 1 January 1960.46 Although the decree was officially only directed at Chinese without Indonesian citizenship, in reality, those with Indonesian citizenship encountered similar distress as the distinction between citizens and aliens was still unclear. ${ }^{47}$ In West Java alone, 9,927 Chinese were forced to move from rural areas to urban places. ${ }^{48}$ There were also Chinese who were sent back to China. According to Thee Kian Wie, around 119,000 Chinese citizens were repatriated to China during 1960-1961. ${ }^{99}$ Some chose to leave for China because they thought that the Presidential Decree had threatened their livelihood. ${ }^{50}$

Earlier in April 1950, the Sukarno government implemented the "Benteng" (Fortress) programme which gave priority to indigenous businesspeople to engage in import-export business and prohibited the Chinese from getting involved in such business. ${ }^{51}$ However, instead of fostering a strong and self-reliant indigenous business class, the programme "resulted in the emergence of the 'Ali Baba' system in which Chinese Indonesians used indigenous Indonesians as 'front men' or 'sleeping partners'". 52 The programme eventually came to an end in the second half of the 1950s. ${ }^{53}$

Although the Sukarno government introduced the above discriminatory policy to reduce Chinese economic interests and assist indigenous businesspeople, it allowed ethnic Chinese to form ethnic-based organisations (ranging from cultural associations to clan groups to business chambers), establish Chinese-language presses, open Chinese-medium schools, and be involved in politics. ${ }^{54}$ In fact, in the new parliament elected in the 1955 election, which was the first national election held in Indonesia after independence, nine appointed seats were reserved for ethnic Chinese. ${ }^{55}$ There were even a few cabinet ministers who were of Chinese origin. ${ }^{56}$ The government allowed the Chinese to keep their ethnic and cultural identity because Sukarno was close to China and hence was relatively tolerant to the Chinese in Indonesia.

\section{The Suharto Years (1966-1998)}

The anti-Communist violence associated with the Cold War instigated by the Suharto-led military after the military takeover on 1 October 1965 took a strong anti-Chinese turn at times from 1965 to $1968 .{ }^{57}$ Many Chinese in Indonesia were accused of being Communist sympathisers and at least two thousands of them were killed from 1965 to 1966.58 The last and worst major anti-Chinese violence broke out at late 1967 and early 1968 in West Kalimantan. The military provoked Dayaks to murder Chinese who were accused of supporting the communist party. ${ }^{59}$ About two to five thousand Chinese were killed and nearly 100,000 Chinese were relocated to coastal cities and towns such as Pontianak and Singkawang. ${ }^{60}$

Later, Suharto's government began to enforce assimilation policies by issuing Presidential Decision No. 240 and Presidential Instruction No. 14 in 1967 to curtail Chinese culture and control the Chinese. ${ }^{61}$ Public displays of Chinese characters were forbidden. Ethnic Chinese were not allowed to openly celebrate Chinese holidays or festivals. Ethnic Chinese organisations were banned except those dealing with health, religion, burial services, sports and recreation. ${ }^{62}$ Chinese-medium schools were closed down. Chineselanguage newspapers were prohibited, except for one produced by the government. ${ }^{63}$ Furthermore, under Presidential Decision No. 240 of 1967, ethnic Chinese were urged to "replace their names with Indonesian-sounding names". ${ }^{64}$

It is worth noting that although many Chinese in Indonesia became more Peranakanised, if not 'Indonesianised', under Suharto's policy of forced assimilation, in some places such as Medan, Pontianak, Singkawang, Bangka and Belitung that are not far away from Malaysia and Singapore, two neighbouring countries with ethnic Chinese communities that still maintain Chinese languages and most Chinese customs, the local Chinese generally can still speak Mandarin and certain Chinese dialects. Many older Chinese can read and 
write Chinese as they had studied in pre-New Order Chinese-medium schools. The younger generation generally cannot read and write Chinese but they can still speak Mandarin and certain Chinese dialects. Moreover, many Chinese in those places also still practise most Chinese customs. 65

During the New Order period, in order to take better control of the Chinese, Suharto's regime also issued regulations and decrees that marginalised and stigmatised the Chinese. For instance, a particular code was attached to the national identity cards and passports of Indonesians of Chinese origin. ${ }^{66}$ This coding system stigmatised the Chinese and "constantly exposed them to discrimination and exploitation by the bureaucracy, police and military" ${ }^{67}$ Chinese Indonesians also had to produce a Citizenship Letter (SBKRI - Surat Bukti Kewarganegaraan Republik Indonesia) to obtain documents such as birth certificates, passports or marriage certificates. ${ }^{68}$ In addition, as mentioned earlier in this article, unwritten barriers restricted the Chinese from politics, public service, military and entrance to public universities. During the New Order era, there were very few ethnic Chinese members of parliament. ${ }^{69}$ In general, the Chinese were only given the right to participate in economic activities. ${ }^{70}$ As a result, as Chang-Yau Hoon notes, "This continuous and intentional official discrimination against the Chinese placed them in a vulnerable position of ethnic and class hostility" ${ }^{71}$ Therefore, it can be said that the assimilation policies were aimed to secure the power of Suharto's regime and were never meant to integrate the Chinese into the general Indonesian population.

The New Order policy, therefore, deliberately excluded the Chinese from politics, and thus many Chinese, as had been the case over the centuries, chose to get involved in economic activities. The New Order also saw the emergence of a substantial number of cukong, Chinese Indonesian capitalists who collaborated with members of the Indonesian power elite, usually from the military and the Suharto family, both of these being the dominant political force during the Suharto era. These cukong included Liem Sioe Liong a.k.a. Sudono Salim, Tjia Kian Liong a.k.a. William Soerjadjaja and Lie Mo Tie a.k.a. Mochtar Riady. They were all owners of conglomerates. The Suharto regime provided protection and various facilities such as privileged access to licenses, contracts and state bank credit to these cukong. In return, the power elite and their family became the Chinese capitalists' business partners. ${ }^{72}$ However, as Suryadinata has maintained, the number of such cukong was small and did not represent Chinese Indonesians in general. ${ }^{73}$ Most of the Chinese in Indonesia were, and still are, owner-managers of small- and medium-scale enterprises or professionals. Nevertheless, the corrupt relationships between a handful of Chinese Indonesian tycoons and power elites greatly influenced indigenous Indonesians' perception of the Chinese. As a result, Chinese Indonesians were generally perceived to be wealthier than indigenous Indonesians, corrupt and opportunistic. The Chinese had no means to rectify this impression since they were socially and politically weak. Consequently, they were exposed to periodic anti-Chinese riots during economic crises and workers' strikes (e.g. the workers' strike in Medan that took place in 1994). ${ }^{74}$

In summary, it can be said that the Chinese in the Dutch East Indies and in the Republic of Indonesia after independence were treated as a "pariah class", powerful in business, but hated for their wealth. 75 They came to be perceived as the 'Other' by the indigenous Indonesians.

\section{Post-Suharto Era (1998-Present)}

Suharto's authoritarian rule ended in May 1998 amid the Asian financial crisis. ${ }^{76}$ Social unrest in Indonesia, aggravated by the financial crisis, escalated and peaked in mid-May in Jakarta, Solo and other parts of the country. Chinese shops and properties were looted and burned down, and as mentioned earlier, it was alleged that many Chinese women were 
brutally tortured, raped and murdered. ${ }^{77}$ According to the Joint Fact-Finding Team (Joint Team) appointed by the Habibie government to investigate the riots, the violence was probably instigated by someone "at the country's 'highest levels' of decision-making" to create a critical upheaval so that martial law could be imposed. ${ }^{78}$ It has also been argued that the violence was instigated by the military to deflect public anger from the Suharto regime and towards the Chinese minority. ${ }^{79}$ However, to date there is still no concrete evidence available and therefore it is difficult to prove such involvement conclusively.

The fall of Suharto has led to a process of democratisation in Indonesia, with the implementation of a few significant institutional reforms. The period of reform and democratisation after the end of the authoritarian regime was also marked by a considerable decline in anti-Chinese violence after May 1998. According to Jacques Bertrand, the killings of May 1998, particularly the alleged mass rape cases, as well as the alleged involvement of the armed forces in the riots, shocked the political elite and Islamic politicians who had been most critical and vocal about Suharto's collusion with Chinese Indonesian conglomerates. They began to sympathise with the Chinese minority and acknowledge that the Chinese had not been treated justly. ${ }^{80}$ Sarah Turner makes a similar remark, "Since 1998 there has been an increased official and general acknowledgement within Indonesia that the ethnic Chinese community received gross injustices during the period of the riots" ${ }^{81}$

The reversal of attitudes toward the Chinese was also catalysed by capital flight and the 'exodus' of Chinese after the events of May 1998. In addition, some Chinese Indonesian tycoons had cooperated with post-New Order governments in investigations about corruption and this contributed further to the easing of the resentment against the Chinese. Bertrand notes that the prosecution and subsequent imprisonment of Bob Hasan, Suharto's long-time crony and golf partner of Chinese descent, "particularly pleased many Indonesians". ${ }^{82}$ In other words, the end of Suharto's regime had removed Hasan, one of the most significant symbols of hostility against the Chinese minority.

Under the influence of a more sympathetic view from Indonesian political elites, Chinese Indonesians have begun to benefit from reforms introduced by subsequent governments. Many discriminatory measures against the Chinese were removed. Most significantly, Suharto's policy of forced assimilation was abandoned. In 2000, President Abdurrahman Wahid sanctioned the publication of Chinese-language print media by issuing Presidential Decision No. 6. The Presidential Decision repealed laws that had prohibited the local publication of Chinese characters in Indonesia during Suharto's presidency and thus Chinese language materials became more freely available. ${ }^{83}$ Many schools were allowed to conduct Chinese language courses. ${ }^{84}$ Besides that, ethnic Chinese were allowed to openly celebrate Chinese festivals. ${ }^{85}$ In fact, in 2002, the government led by President Megawati Sukarnoputri made the Lunar New year a state holiday from 2003 onwards through the issuance of Presidential Decision No. 19.86 In July 2006, under Susilo Bambang Yudhoyono's presidency, the Indonesian Parliament passed Law No. 12, which was a landmark law on citizenship that did away with the distinction between 'indigenous' and 'non-indigenous' Indonesians - long cited by Chinese Indonesians as discrimination by redefining 'indigenous Indonesian' to include all people born in Indonesia and/or to Indonesian parents, and who have never assumed foreign citizenship. ${ }^{87}$ Under the new law, Chinese Indonesians will no longer need to produce proof of their citizenship or undergo the naturalisation process as long as they were born to parents who are Indonesian citizens. .8 They are also allowed to hold government posts, including the presidency, that were formerly closed to them. Therefore, it can be said that the reversal of attitudes toward the Chinese was also due to the rise of political leaders who were open-minded and sympathetic to the situation of the Chinese.

Hence, the fall of Suharto was a turning point for the Chinese in Indonesia to openly and actively participate in the socio-political arena. A few Chinese have also made use of the 
democratic environment to participate in national as well as local politics and establish ethnic Chinese social and cultural organisations. Many Chinese organisations that were previously closed down re-emerged and those that had been converted to foundations dealing with health, religion, burial services, sports or recreation began to include again socio-cultural activities that openly celebrate and promote Chinese traditions and culture in their routine activities. Two major ethnic Chinese mass organisations in post-Suharto Indonesia, i.e. the Indonesian Chinese Social Association (PSMTI - Paguyuban Sosial Marga Tionghoa Indonesia) and the Chinese Indonesian Association (INTI - Perhimpunan Indonesia Tionghoa), have branches extended to various parts of Indonesia. The objectives of both organisations are to fight for the interests of Chinese Indonesians, to promote solidarity between ethnic Chinese and indigenous Indonesians, to promote social and cultural issues among Chinese Indonesians, and to advocate the entry of Chinese Indonesians into electoral politics. ${ }^{89}$

There are also Chinese Indonesians who actively participate in formal politics and run for public office under different political parties during general elections. There have been several Chinese elected as parliamentarians and local government heads. Moreover, there have been at least six cabinet ministers who are Chinese. ${ }^{90}$

In addition, the rise of China as an economic power also improved the foreign relations between Indonesia and China. Post-Suharto governments no longer perceive China as an ideologically threatening country. Instead, they see China "as an economic powerhouse providing positive spillovers to its cash-strapped neighbours in Southeast Asia". ${ }^{11}$ The government is keen to attract more Chinese businesses to invest in Indonesia in order to accelerate and expand economic development in the country. These efforts of the Indonesian government have coincided with China's pursuit of friendly relations with Southeast Asian countries. A few Chinese organisations in Indonesia are in a good position to help the government to establish economic ties with China since the leaders are wellconnected to state officials and businesspeople in China. They are thus able to utilise their intra-ethnic linkages and social networks in China to assist the government to establish business connections with China. ${ }^{92}$

\section{Conclusion}

From the above discussion, it is obvious that the position of ethnic Chinese in Indonesia was shaped by both domestic and external factors. These included the interests and agendas of the power-holders, the anti-communist politics associated with the Cold War, the rise of open-minded Indonesian political leaders, Indonesia-China relations and the globalisation of the economic position of China. It can therefore be concluded that as long as open-minded political leaders are in power and that both Indonesia and China maintain good foreign relations with each other, the Chinese in Indonesia will enjoy a less vulnerable and more secure position.

\section{Note}

1 Aris Ananta, Eva Nurvidya Arifin and Bakhtiar, 'Chinese Indonesians in Indonesia and the Province of Riau Archipelago: A Demographic Analysis', in Leo Suryadinata (ed.), Ethnic Chinese in Contemporary Indonesia, Singapore: Institute of Southeast Asian Studies, 2008, p. 20.

2 Ibid., p. 23, Table 2.1; Aris Ananta et al., 'Changing Ethnic Composition: Indonesia, 2000-2010', International Union for the Scientific Study of Population (IUSSP) website, 2013, p. 14, Table 2, accessed 21 November 2013, http://www.iussp.org/sites/default/files/event_call_for_papers/IUSSP\%20Ethnicity\%20Indon esia $\% 20$ Poster $\% 20$ Section $\% 20 \mathrm{G} \% 202708 \% 202013 \% 20$ revised.pdf. This figure was calculated directly from the raw data of the 2000 and 2010 population censuses. The figure, which is 
significantly smaller than that in 1930, is based on self-identification. Only those who identified themselves as Chinese were recorded as ethnic Chinese.

3 Anthony Reid, Southeast Asia in the Age of Commerce 1450-1680, Volume Two: Expansion and Crisis, New Haven: Yale University Press, 1993, p. 228; John T. Sidel, Riots, Pogroms, Jihad: Religious Violence in Indonesia, Ithaca: Cornell University Press, 2006, p. 19.

4 Anthony Reid, 'Economic and Social Change, c. 1400-1800', in Nicholas Tarling (ed.), The Cambridge History of Southeast Asia Volume One: From Early Times to c. 1800, Cambridge: Cambridge University Press, 1992, p. 497.

5 Eddie Lembong, 'Indonesian Government Policies and the Ethnic Chinese: Some Recent Developments', in Leo Suryadinata (ed.), Ethnic Chinese in Contemporary Indonesia, Singapore: Institute of Southeast Asian Studies, 2008, p. 48.

6 Mona Lohanda, The Kapitan Cina of Batavia 1837-1942, Jakarta: Penerbit Djambatan, 1996, p. 53.

7 Leo Suryadinata, 'Chinese Economic Elites in Indonesia: A Preliminary Study', in Jennifer W. Cushman and Wang Gungwu (eds.), Changing Identities of the Southeast Asian Chinese since World War II, Hong Kong: Hong Kong University Press, 1988, p. 262; Christian Chua, Chinese Big Business in Indonesia, Abingdon: Routledge, 2008, p. 31.

8 Ming Govaars, Dutch Colonial Education: The Chinese Experience in Indonesia, 1900-1942, Singapore: Chinese Heritage Centre, 2005, p. 20.

9 Leo Suryadinata, 'The State and Chinese Minority in Indonesia', in Leo Suryadinata (ed.), Chinese Adaptation and Diversity: Essays on Society and Literature in Indonesia, Malaysia \& Singapore, Singapore: Singapore University Press, 1993, p. 83.

10 The Siauw Giap (Chinese name unknown), 'Juliuguo Zongjiao Dui Dongnanya Huaqiao Tonghua De Yingxiang' (Religion and Overseas Chinese Assimilation in Southeast Asian Countries) (Translated by Zhang Qing Jiang from Chinese original), Journal of Southeast Asian Researches, Vol. 3, 1967, p. 91.

11 Lea E. Williams, Overseas Chinese Nationalism: The Genesis of the Pan-Chinese Movement in Indonesia, 1900-1916, Glencoe: The Free Press, 1960, p. 24.

12 Ming Govaars, Dutch Colonial Education, p. 27; Lea E. Williams, Overseas Chinese Nationalism, p. 25.

13 Ming Govaars, Dutch Colonial Education, p. 28.

14 Leo Suryadinata, 'The State and Chinese Minority in Indonesia', pp. 81-82.

15 Lea E. Williams, Overseas Chinese Nationalism, pp. 25-27.

16 C. Fasseur, 'Cornerstone and Stumbling Block: Racial Classification and the Late Colonial State in Indonesia', in Robert Cribb (ed.), The Late Colonial State in Indonesia: Political and Economic Foundations of the Netherlands Indies 1880-1942, Leiden: KITLV Press, 1994, p. 37.

17 For the origins of the nationalist movement among indigenous Indonesians in the early twentieth century and its relationship with the Chinese in the Dutch East Indies, see Mona Lohanda, Growing Pains: The Chinese and the Dutch in Colonial Java, 1890-1942, Jakarta: Yayasan Cipta Loka Caraka, 2002, pp. 171-205 and Takashi Shiraishi, 'Anti-Sinicism in Java's New Order', in Daniel Chirot and Anthony Reid (eds.), Essential Outsider: Chinese and Jews in the Modern Transformation of Southeast Asia and Central Europe, Seattle: University of Washington Press, 1997, pp. 187-207.

18 Ming Govaars, Dutch Colonial Education, p. 49. The Boxer Uprising was an anti-foreigner movement that took place in China in 1900. For the origins of the uprising, see Joseph W. Esherick, The Origins of the Boxer Uprising, Berkeley: University of California Press, 1987. Ming Govaars, Dutch Colonial Education, p. 49.

20 Ibid.

21 English-translated text of the 1909 Nationality Law of China, cited in Leo Suryadinata, 'China's Citizenship Law and the Chinese in Southeast Asia', in M. Barry Hooker (ed.), Law and the Chinese in Southeast Asia, Singapore: Institute of Southeast Asian Studies, 2002, pp. 185-192; Ming Govaars, Dutch Colonial Education, p. 50; Donald E. Willmott, The National Status of the Chinese in Indonesia 1900-1958, Ithaca: Cornell Modern Indonesia Project, 1961, p. 14. Previously, the Manchu government prohibited the emigration of Chinese and those returning to China from abroad were subjected to death penalty. See Lim Joo Hock, 'Chinese Female Immigration into the Straits Settlements, 1860-1901', Journal of the South Seas Society, Vol. 22, 1967, p. 63 and Chong Peng Hong, 'Chinese Female Immigration to the Straits Settlements from 1901 to 1941', B.A. Academic Exercise, National University of Singapore, Singapore, 1983/84, p. 3. 

[From Ancient Times to 1949]), Guangzhou: Guangdong Gaodeng Jiaoyu Cubanshe, 2005, p. 390. Conventionally, scholars have divided them into peranakan and totok. The peranakan were localborn and acculturated Chinese. Some of them were products of intermarriage between Chinese male immigrants and local indigenous women. They had been residing in Indonesia for centuries. Although the peranakan still identified themselves as Chinese, they had adopted many elements of the majority Indonesian indigenous culture and some of them could not speak Chinese. The totok, on the other hand, were pure-blood Chinese who were born in China and migrated to the Indies. They spoke Chinese and maintained most Chinese customs and cultural traditions. In addition, they were generally more politically oriented to China. Mass Chinese immigration to the Indies took place in the second half of the nineteenth century due to political turmoil in China. The immigrants included a significant number of women and it became possible for Chinese men to marry China-born women rather than peranakan women. Descendants of these new immigrants usually remained culturally totok Chinese and formed the distinct and separate totok community. See G. William Skinner, 'The Chinese of Java', in Morton Herbert (ed.), Colloquium on Overseas Chinese, New York: International Secretariat, Institute of Pacific Relations, 1958, p. 2; Mary F. Somers, Peranakan Chinese Politics in Indonesia, Ithaca: Cornell Modern Indonesia Project, 1964, p. 4. Collective Memory and the Media, Amherst: Cambria Press, 2009, p. 2.

34 Mary F. Somers, 'Peranakan Chinese Politics in Indonesia', PhD Thesis, Cornell University, United States of America, 1965, pp. 110-119; Mary F. Somers Heidhues, Southeast Asia's Chinese Minorities, Hawthorn, Victoria: Longman, 1974, pp. 101-102, 109; Robert Cribb, Gangsters and Revolutionaries: The Jakarta People's Militia and the Indonesian Revolution, 1945-1949, Sydney: Allen and Unwin, 1991, pp. 53, 111.

35 Mary F. Somers Heidhues, Southeast Asia's Chinese, p. 109; Chang-Yau Hoon, Chinese Identity in Post-Suharto Indonesia: Culture, Politics and Media, Brighton: Sussex Academic Press, 2008, p. 33. Aimee Dawis, The Chinese of Indonesia and Their Search for Identity, p. 2.

Charles A. Coppel, Indonesian Chinese in Crisis, p. 26.

Michael R. Godley, 'The Sojourners: Returned Overseas Chinese in the People's Republic of China', Pacific Affairs, Vol. 62, No. 3, Autumn 1989, pp. 330-352; Hui Yew-Foong, Strangers at Home: History and Subjectivity among the Chinese Communities of West Kalimantan, Indonesia, Leiden: Brill, 2011, pp. 98-99. 


\section{Id} Leo Suryadinata, Pribumi Indonesians, the Chinese Minority and China, pp. 149-153; Leo Suryadinata, 'The State and Chinese Minority in Indonesia', pp. 86-88; Leo Suryadinata, The Culture of the Chinese Minority in Indonesia, pp. 253-259. Leo Suryadinata, Pribumi Indonesians, the Chinese Minority and China, pp. 14, n10, 14, n11; Leo Suryadinata, 'The State and Chinese Minority in Indonesia', p. 88.

57 J.A.C. Mackie, 'Anti-Chinese Outbreaks in Indonesia, 1959-68', pp. 77-138; Jamie S. Davidson, From Rebellion to Riots: Collective Violence on Indonesian Borneo, Singapore: NUS Press, 2009, pp. 4784; Hui Yew-Foong, Strangers at Home, pp. 115-146; Yen-ling Tsai and Douglas Kammen, 'Anticommunist Violence and the Ethnic Chinese in Medan, North Sumatra', in Douglas Kammen and Katharine McGregor (eds.), The Contours of Mass Violence in Indonesia, 1965-68, Singapore: NUS Press, 2012, pp. 131-155. For a comprehensive discussion on the background of the military takeover and the subsequent mass violence against the Indonesian Communist Party (PKI - Partai Komunis Indonesia) and the Left, see Douglas Kammen and Katharine McGregor (eds.), The Contours of Mass Violence in Indonesia, 1965-68, Singapore: NUS Press, 2012.

58 Charles A. Coppel, Indonesian Chinese in Crisis, p. 58.

59 J.A.C. Mackie, 'Anti-Chinese Outbreaks in Indonesia, 1959-68', pp. 126-128; Jamie S. Davidson, From Rebellion to Riots, pp. 47-84; Hui Yew-Foong, Strangers at Home, pp. 115-146.

60 Jamie S. Davidson, From Rebellion to Riots, pp. 47-84. It should be noted that the anti-Communist violence was never anti-Chinese massacres in general, although the massacres that broke out in West Kalimantan in 1967 and 1968 was targeted exclusively at Chinese. There were about 500,000 people killed in 1965-1966 and the victims were mostly indigenous Indonesians who were members and associates of the Indonesian Communist Party (PKI) (See Robert Cribb and Charles A. Coppel, 'A Genocide That Never Was: Explaining the Myth of anti-Chinese Massacres in 
Indonesia, 1965-66', Journal of Genocide Research, Vol. 11, No. 4, December 2009, pp. 447-465; Yenling Tsai and Douglas Kammen, 'Anti-communist Violence and the Ethnic Chinese in Medan, North Sumatra', pp. 131-155).

61 Original text of Presidential Decision No. 240/1967, available at Indonesia's Ministry of Research, Technology and Higher Education's website, accessed 30 August 2016, http://jdih.ristekdikti.go.id/?q=system/files/perundangan/784730057.pdf; original text of Presidential Instruction 14/1967, available at Hukum Online website, accessed 30 August 2016, http://www.hukumonline.com/pusatdata/download/1t51cbd8bc84ecc/node/1t51cbd78fd5428.

Some Chinese organisations therefore converted to charitable foundations (yayasan) that focused on health, religion, burial services, sports or recreation in order to continue to operate.

63 Charles A. Coppel, Indonesian Chinese in Crisis, p. 165; Charles A. Coppel, Studying Ethnic Chinese in Indonesia, Singapore: Singapore Society of Asian Studies, 2002, pp. 22-23; Leo Suryadinata, Pribumi Indonesians, the Chinese Minority and China, pp. 153-164; Christian Chua, Chinese Big Business in Indonesia, pp. 39-40.

In fact, a lecturer at the University of Indonesia once told me that many people in Jakarta deemed Chinese Indonesians from 'PBBM' (Pontianak, Bangka, Belitung and Medan) as less assimilated and exclusive. Personal communication with Timothy (pseudonym) at the University of Indonesia, Depok, 31 January 2011.

66 Mely G. Tan, 'The Social and Cultural Dimensions of the Role of Ethnic Chinese in Indonesian Society', in Audrey Kahin (ed.), Indonesia: The Role of the Indonesian Chinese in Shaping Modern Indonesian Life, Ithaca: Cornell Southeast Asia Program, 1991, p. 123; Nobuhiro Aizawa, 'Assimilation, Differentiation, and Depoliticization: Chinese Indonesians and the Ministry of Home Affairs in Suharto's Indonesia', in Marleen Dieleman, Juliette Koning and Peter Post (eds.), Chinese Indonesians and Regime Change, Leiden: Brill, 2011, pp. 60-61.

68 Nobuhiro Aizawa, 'Assimilation, Differentiation, and Depoliticization', p. 61

69 A few months before the collapse of the New Order regime, Suharto appointed Bob Hasan a.k.a. The Kian Seng, his long-time crony and golf partner of Chinese descent minister of trade and industry. But Hasan was adopted by an indigenous Muslim military officer since he was little and had been highly assimilated into indigenous society. Hence, as Li Zhuo Hui, chief editor of Indonesian Chinese-language press Guoji Ribao points out, the Chinese community did not perceive Hasan as an "ethnic Chinese businessperson" and did not think he represented the Chinese community. See Sam Setyautama, Tokoh-tokoh Etnis Tionghoa Di Indonesia (Ethnic Chinese Celebrities in Indonesia), Jakarta: Kepustakaan Populer Gramedia [KPG], 2008, p. 410 and Li Zhuo Hui, Yinhua Canzheng Yu Guojia Jianshe (The Political Participation of Chinese Indonesians and Nation Building), Jakarta: Mandarin Book Store, 2007, p. 153.

70 Christian Chua, Chinese Big Business in Indonesia, p. 42.

71 Chang-Yau Hoon, 'Assimilation, Multiculturalism, Hybridity: The Dilemmas of the Ethnic Chinese in Post-Suharto Indonesia', Asian Ethnicity, Vol. 7, No. 2, June 2006, p. 153.

72 Richard Robison, Indonesia: The Rise of Capital, North Sydney: Allen \& Unwin, 1986, pp. 271-322; Leo Suryadinata, The Culture of the Chinese Minority in Indonesia, pp. 33-34.

73 Leo Suryadinata, Elections and Politics in Indonesia, Singapore: Institute of Southeast Asian Studies, 2002, p. 15.

74 Jemma Purdey, Anti-Chinese Violence in Indonesia, 1996-1999, Singapore: Singapore University Press, 2006, pp. 77-141; Yang Tsung Rong, 'The Indonesian Chinese and the Ethnic Issue: A Case Study of the Social Riots in the Late New Order (1994-1997)', in Lee Guan Kin (ed.), Demarcating Ethnicity in New Nations: Cases of the Chinese in Singapore, Malaysia, and Indonesia, Singapore: Konrad-Adenauer-Stiftung, 2006, pp. 227-249.

75 Christian Chua, Chinese Big Business in Indonesia, p. 23.

76 Leo Suryadinata, 'Chinese Politics in Post-Suharto's Indonesia: Beyond the Ethnic Approach?' Asian Survey, Vol. 41, No. 3, May/June 2001, p. 506.

77 Jamie Mackie, 'Tackling 'the Chinese problem", in Geoff Forrester (ed.), Post-Soeharto Indonesia: Renewal or Chaos, Singapore: Institute of Southeast Asian Studies, 1999, p. 189. However, as Chang-Yau Hoon stated in his published dissertation, the rapes are still "a contested issue as 
there has been no consensus on the number of rape victims" and "there is still a general denial of the rapes in Indonesia's official discourse". See Chang-Yau Hoon, Chinese Identity in Post-Suharto Indonesia, p. 46.

The Joint Fact-Finding Team (TGPF), 'The Final Report of the Joint Fact-Finding Team (TGPF) on the May 13-15, 1998 Riot Executive Summary', accessed 12 November 2013, http://www.our21.com/Indo/TGPF.html.

79 Ariel Heryanto, 'Rape, Race, and Reporting', in Arief Budiman, Barbara Hatley and Damien Kingsbury (eds.), Reformasi: Crisis and change in Indonesia, Clayton: Monash Asia Institute, Monash University, 1999, p. 327.

80 Jacques Bertrand, Nationalism and Ethnic Conflict in Indonesia, Cambridge: Cambridge University Press, 2004, pp. 68-69.

81 Sarah Turner, 'Speaking Out: Chinese Indonesians after Suharto', Asian Ethnicity, Vol. 4, No. 3, October 2003, p. 347.

82 Jacques Bertrand, Nationalism and Ethnic Conflict in Indonesia, p. 69.

83 Original text of Presidential Decision No. 6/2000, available at Hukum Online website, accessed 30 August 2016, http://www.hukumonline.com/pusatdata/download/fl27181/node/19054.

84 However, Chinese-medium schools have not been re-opened. See Eddie Lembong, 'Indonesian Government Policies and the Ethnic Chinese', p. 54

85 Original text of Presidential Decision No. 6/2000.

86 Original text of Presidential Decision No. 19/2002, available at Hukum Online website, accessed 30 August 2016, http://www.hukumonline.com/pusatdata/download/fl25136/node/18491; Amy Freedman, 'Political Institutions and Ethnic Chinese Identity in Indonesia', Asian Ethnicity, Vol. 4, No. 3, October 2003, p. 447.

87 Original text of Law No. 12/2006, available at Hukum online website, accessed 30 August 2016, http://www.hukumonline.com/pusatdata/download/lt4c20ca254ec30/node/25702.

88 D. Asmarani, 'Indonesia Passes Landmark Citizenship Law', Indonesian Reports - LOG, Vol. 23, No. 29, 2006, p. 1.

89 INTI is actually a breakaway faction of PSMTI. PSMTI established itself as an exclusively ethnic Chinese organisation in which only Chinese Indonesians could become full members. NonChinese Indonesians could only become honorary members. Some of the original members were uncomfortable with such a policy and had subsequently left to form INTI. INTI accepts all Indonesian citizens who agree with the objective of the organisation to join as members. See Susan Giblin, 'Overcoming Stereotypes? Chinese Indonesian Civil Society Groups in Post-Suharto Indonesia', Asian Ethnicity, Vol. 4, No. 3, October 2003, pp. 357-358; Leo Suryadinata, 'Chinese Politics in Post-Suharto's Indonesia', pp. 512-514; Chang-Yau Hoon, Chinese Identity in PostSuharto Indonesia, pp. 77-79.

90 Charles A. Coppel, 'Anti-Chinese Violence in Indonesia after Soeharto', in Leo Suryadinata (ed.), Ethnic Chinese in Contemporary Indonesia, Singapore: Institute of Southeast Asian Studies, 2008, p. 120; The Jakarta Globe, 25 Sep. 2012; Inhua Daily, 28 Jul. 2016; The Jakarta Post, 19 Oct. 2011; The Jakarta Post, 26 Oct. 2014; The Jakarta Post, 27 Jul. 2016.

91 Zhao Hong, 'China-Indonesia economic relations: Challenges and prospects', ISEAS Perspectives, No. 42, 2013, p. 4.

92 Jiang Zhen Peng and Ding Li Xing, 'Yindunixiya Minzhuhua Gaige Yilai Huaren Jingji De Xinfazhan Ji Qiqishi' (The Latest Development and Indication of Ethnic Chinese Economic Activities since the Democratisation in Indonesia), The Institute of Contemporary China Studies's website, 6 April 2011, accessed 26 June 2016, http://www.iccs.cn/contents/602/10509_5.html.2011. 